\author{
Abstracta Iranica \\ Abstracta Iranica Revue bibliographique pour le domaine irano-aryen \\ Volume 37-38-39 | 2018 \\ Comptes rendus des publications de 2014-2016
}

\title{
Sebastian P. Brock. « Les controverses christologiques en syriaque : controverses réelles et controverses imaginées »
}

Christelle Jullien

\author{
(2) OpenEdition \\ Journals \\ Édition électronique \\ URL : http://journals.openedition.org/abstractairanica/44611 \\ DOI : 10.4000/abstractairanica.44611 \\ ISBN : 1961-960X \\ ISSN : 1961-960X \\ Éditeur : \\ CNRS (UMR 7528 Mondes iraniens et indiens), Éditions de l'IFRI
}

\section{Référence électronique}

Christelle Jullien, « Sebastian P. Brock. « Les controverses christologiques en syriaque : controverses réelles et controverses imaginées » », Abstracta Iranica [En ligne], Volume 37-38-39 | 2018, document 24, mis en ligne le 30 décembre 2018, consulté le 26 septembre 2020. URL : http://

journals.openedition.org/abstractairanica/44611 ; DOI : https://doi.org/10.4000/abstractairanica 44611

Ce document a été généré automatiquement le 26 septembre 2020.

Tous droits réservés 


\title{
Sebastian P. Brock. « Les controverses christologiques en syriaque : controverses réelles et controverses imaginées »
}

\author{
Christelle Jullien
}

\section{RÉFÉRENCE}

Sebastian P. Brock. «Les controverses christologiques en syriaque : controverses réelles et controverses imaginées » in Flavia Ruani (éd.). Les controverses religieuses en syriaque. Paris : Geuthner, 2016, p. 105-118. (Études syriaques 13)

1 Les controverses entre les trois principales mouvances christologiques autour des décisions du concile de Chalcédoine proviennent seulement des sources syriaques. L'A. relève les ambiguïtés de certains termes théologiques "techniques" usuels, et par conséquent les confusions générées par leur usage. La controverse en syriaque a pris différentes formes, ici présentées en une brève typologie. Deux textes sont étudiés plus en détail: le premier a trait à un vrai dialogue - les échanges entre évêques chalcédoniens et miaphysites à Constantinople en 532 -; le second est une polémique imaginaire - un dialogue entre Cyrille d'Alexandrie et Nestorius - élaborée et transmise par la tradition syriaque orientale. 


\section{AUTEURS}

\section{CHRISTELLE JULLIEN}

CNRS, Mondes iranien et indien, Paris 